\title{
Effects of Hydro-priming and Seed Size on the Germination, Root, and Shoot of Peanut (Arachis hypogaea L. var. NSIC Pn18) Grown under Drought Conditions
}

Van Marie

Editha CAGASAND,

Ulysses CAGASAN (D)

Department of Agronomy, Visayas State University, College of Agriculture and Food Science,

Visca, Baybay City, Leyte, Philippines

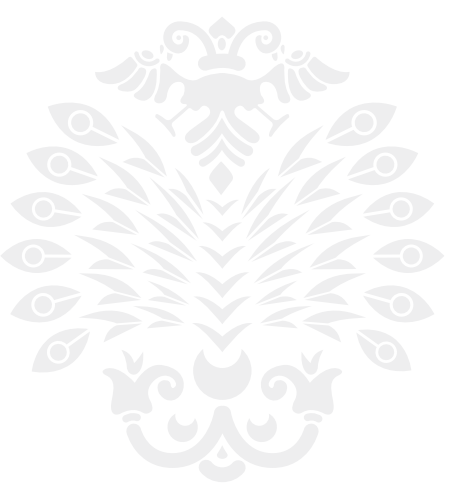

Received: 03.04.2021

Accepted: 02.10.2021

Corresponding Author: Ulysses CAGASAN

E-mail: ulycagasan@vsu.edu.ph

Cite this article as: Cagasan V.M. E., \& Cagasan, U. (2022). Effects of

Hydro-priming and Seed Size on the Germination, Root, and Shoot of Peanut (Arachis Hypogaea L. var. NSIC Pn18) Grown Under Drought Conditions. Atatürk University Journal of Agricultural Faculty, 2022;53(1):1-7.

\section{(c) (i) (8)}

Content of this journal is licensed under a Creative Commons Attribution-NonCommercial 4.0 International License.

\author{
Ön Islatma ve Tohum Büyüklüğünün Kurak \\ Koşullarında Yetiştirilen Yer Fıstığında (Arachis \\ hypogaea L. var. NSIC Pn19) Çimlenme, Kök ve \\ Sürgün Üzerine Etkileri
}

\begin{abstract}
This study aimed to assess the effects of hydro-priming duration and peanut seed size on the germination performance and the root and shoot characteristics of peanut seedlings under drought conditions. Two experiments were conducted under the laboratory and nursery. Peanut seed sizes (S1: small seeds and S2: large seeds) designated as the main plots, and duration of priming (P1: O hour, P2: 5 hours, and P3: 10 hours) was considered as the subplots. A $2 \times 3$ split-plot completely randomized design with three replications was used. Ten small and ten large seeds were placed in $4 \times 4$ inch plastic containers for laboratory experiment and $25 \times 25 \mathrm{~cm}$ cellophane for pot experiment per treatment filled with dry soil at $10 \%$ moisture content. Large seeds soaked at 5-10 hours emerged earlier than the unsoaked seeds in this study. Final germination enhanced in bigger seeds also resulted in an increase in the germination index (seeds day ${ }^{-1}$ ) and the seedling vigor index. Likewise, larger seeds produced shorter shoots and plant height but broader shoots with more leaves. It is recommended that bigger seeds can be a good source of planting materials when planted in drought conditions and primed at 5-10 hours. However, unprimed smaller seeds can be used as planting materials in moist soil conditions. The interaction effect was noted on the fresh shoot weight of peanut plants as affected by seed size and hydro-priming. Higher fresh shoot weight of peanut plants when exposed to priming regardless of the seed size was obtained.
\end{abstract}

Keywords: Germination, peanut, priming, seed size, vigor

öz

Bu çalışma ile kurak koşullarında tohum ıslatma süresi ve yer fıstığı tohum boyutunun yer fıstığı tohumlarının kök ve sürgün özellikleri ile çimlenme performansı üzerine etkilerini değerlendirmek amaçlanmıştır. Laboratuvar ve fide üretim şartlarında iki deneme yürütülmüştür. Yer fıstığı tohum büyüklüğü (S1-küçük tohum ve S2-büyük tohum) ana parsel, tohumların suyla muamele edilme süresi (P1-O saat, P2-5 saat ve P3-10 saat) alt parsel olarak belirlenmiştir. Deneme $2 \times 3$ Şansa Bağlı Tam Bloklar deneme deseninde bölünmüş parseller düzenlemesine göre 3 tekerrürlü olarak tasarlanmıştır. Laboratuvar denemesi için 10 adet küçük ve 10 adet büyük tohum $4 \times 4$ inçlik plastik kaplara yerleştirilmiş ve saksı denemeleri için ise \%10 nem içeriğine sahip kuru toprakla doldurulmuş $25 \mathrm{~cm} \times 25 \mathrm{~cm}$ selofan kullanılmıştır. Çalışmada, 5 ve10 saat ıslatılan tohumların ıslatılmamış tohumlardan daha erken çıkış yaptığı tespit edilmiştir. Büyük tohumlarda çimlenme artırılmış, ayrıca çimlenme indeksinde (tohumlar/gün) ve fide canlılık indeksinde bir artış olmuştur. Benzer şekilde, büyük tohumlar daha kısa sürgün ve bitki boyu oluşturmuş, ancak daha fazla yapraklı sürgünler meydana gelmiştir. Kurak koşullarda daha büyük tohumlar ve 5 ile 10 saat ıslatılan tohumların daha iyi bitki ekim materyali olabileceği tavsiye edilmiştir. Bununla birlikte, nemli toprak koşullarında ekim materyali olarak ıslatılmamış küçük tohumların kullanılabileceği belirlenmiştir. Fıstık bitkilerinin taze sürgün ağırlığı (FSW) üzerine tohum büyüklüğü ve ön ıslatma 
interaksiyon etkisi kaydedilmiş, tohum büyüklüğüne bakılmaksızın ön ıslatma uygulanan yerfıstığı bitkilerinin daha yüksek FSW oluşturduğu tespit edilmiştir.

Anahtar Kelimeler: Çimlenme, yer fıstığı, ön ıslatma, tohum büyüklüğü, canlılık

\section{Introduction}

Peanut (Arachis hypogaea L.), also known as groundnut, is a self-pollinating, indeterminate, annual herbaceous legume crop (Adinya et al., 2016). It is considered the 13th most important food crop globally (Taru et al., 2018). Yakubu et al. (2020) noted that peanuts could fix atmospheric nitrogen at the rate of 150$206 \mathrm{~kg} / \mathrm{ha}$ annually in soils through root nodule bacterium. Thus, it can help improve soil fertility and productivity. However, this crop production is not enough to satisfy the industry's demand because of low production per unit area and time (Papong \& Cagasan, 2020). Hence, researchers are trying to find ways to improve the productivity of the crop. One possible way to improve peanut production is to ensure successful crop establishment by promoting high seedling vigor, especially when the crop is planted under adverse conditions. Good crop establishment through the use of seed priming techniques is considered an essential factor for most field crops' success, as it can contribute to uniform plant growth and maturity, better competition with weeds, and high productivity. Thus, priming techniques must be studied to improve the germination rates and quality of seedlings. Hydropriming is a simple procedure that partially hydrates seed in a controlled environment, followed by seed drying, so that germination processes begin without radicle emergence (Pill \& Necker, 2001). This approach is helpful for several crops where unfavorable soil conditions can constrain germination and emergence. According to Sarcol and Cagasan (2016) in general, dry season cropping gives a higher yield with high seed quality than rainy season cropping. However, the germination rate makes it a problem for the peanut farmers during dry season planting because of low moisture contents during early crop establishment.

Moreover, some research findings show that large seeds have a better germination rate than small seeds (Ekpo, 2004). It has been reported that seed size correlates with seed vigor and that large seeds tend to produce more vigorous seedlings and better stand and more likely to emerge from greater depth than those from small seeds (Sanderson et al., 2002). Plants from larger seeds have been reported to produce bigger seed yield than those from small kernels during dry season cropping. Other research results indicated better germination and vigor in small and large-sized seeds. However, there is still no specific publication written regarding the effects of seed size on peanut crops. Therefore, improving seed vigor is a primary objective of the industry on seed production to enhance crop establishment's critical and yield-defining stage. Nevertheless, after sowing, low vigor of seeds or adverse environmental conditions may cause slow seed germination and unreliable seedling emergence under field conditions. This study was conducted to: (1) assess the effects of hydro-priming duration on the germination performance of peanut seeds and the root and shoot characteristics of peanut seedlings, (2) determine the effects of seed size on the germination rate of peanut seeds and the root and shoot characteristics of peanut seedlings and (3) determine the effects of hydro-priming duration and seed size on yield components of seed size and the germination rate of peanuts seeds and the root and shoot characteristics of the peanut seedlings.

\section{Methods}

The study was conducted in the laboratory and nursery area of the Department of Agronomy, College of Agriculture and Food Science, Visayas State University, Baybay City, Leyte, from March 5 to 25,2020 . The newly NSIC-recommended peanut variety (NSIC Pn18) was used. Peanuts were shelled, seeds were segregated into small $(<20 \mathrm{~g})$ and large ( $>20 \mathrm{~g})$, and soaked in distilled water following the duration of priming/soaking based on the specified treatments. The experiments were conducted under laboratory and nursery (pot experiment) conditions (Figure 1).

The laboratory and nursery experiments were laid out in a $2 \times 3$ split-plot, completely randomized design (CRD) with three replications. Ten small and ten large seeds (pre-germinated based on the specified treatments) were placed in a container $(25 \times 25$ $\mathrm{cm})$ per treatment filled with dry soil. The different sizes of peanut seeds $\left(\mathrm{S}_{1}-\right.$ small seeds and $\mathrm{S}_{2}$ - large Seeds) were designated as the main plots, and priming duration $\left(\mathrm{P}_{1}-\mathrm{O}\right.$ hour, $\mathrm{P}_{2}-5$ hours, and $\mathrm{P}_{3}-10$ hours) was considered as the subplots.

\section{Data Gathered}

The following germination parameters were determined under laboratory and nursery conditions:

1. Final germination (FG) at the end of the experiment was calculated using the following equation:

$F G=N_{g} / N_{t} \times 100$

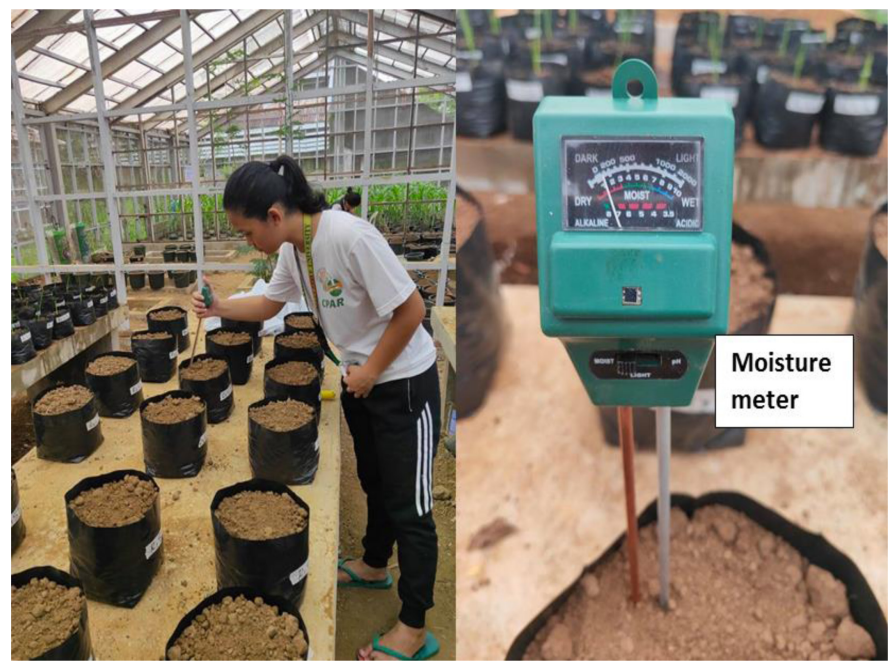

Figure 1.

Preparation of the Pots for Nursery Experiment Using Clay Loam Soil with Less than 10\%MC (dry soil/drought condition) as a Medium for Peanut Germination Study. 
where $N_{\mathrm{g}}$ is the number of germinated seeds and $N_{\mathrm{t}}$ is the total number of seeds.

2. Germination speed (GS) (also known as germination rate) was calculated following the equation:

$\mathrm{GS}=\sum \mathrm{nt} / \sum \mathrm{n}$

where $n$ is the number of normal germinated seeds at time $t$.

3. Timson's germination index (TGI) was calculated with the use of the equation:

$\mathrm{TGl}=\sum \mathrm{G} / \mathrm{t}$

where $G$ is the percentage of germinated seeds at 2-day intervals and $t$ is the total germination period.

4. Mean germination time (MGT) was calculated following the equation:

$M G T=\frac{\sum(n 1 T 1+n 2 T 2+\cdots \cdot+n k T k)}{\sum(n 1+n 2+\cdots \cdot+n k)}$

where $n$ is the number of newly germinated seeds and $T$ is the time from the beginning of the experiment.

5. Mean daily germination (MDG) was calculated following equation:

$M D G=\frac{F G}{T}$

where $F G$ is the final germination and $T$ is the number of days after the start of the test.

1. Seed vigor index (SVI) was calculated by multiplying germination (\%) and seedling length. This was done using the formula below:

$S V I=[$ Seedling length $] \times[$ Final germination $]$

Vigor testing did not only measure the percentage of viable seed in a sample but also reflected the ability of those seeds to produce normal seedlings under less than optimum growing conditions similar to those which may occur in the field. High values of SVI indicate a vigorous seed lot.

\section{Nursery Pot Experiment}

1. Days from sowing to emergence: this was gathered by counting the number of days from sowing to $50 \%$ seed emergence from the five sample plants that emerged in the soil media.

2. Days to flowering: this was gathered by recording the number of days from sowing to $50 \%$ flowering from the treatment plants from the three sample pots in each treatment.

3. Seedling root length $(\mathrm{cm})$ : this was gathered by measuring the length of roots $(\mathrm{cm})$ from the five sample plants 20 days after sowing.

4. Seedling shoot length $(\mathrm{cm})$ : this was gathered by measuring the length of shoots $(\mathrm{cm})$ from five sample plants 20 days after sowing.
5. Seedling root fresh weight ( $g$ plant ${ }^{-1}$ ): this was gathered by weighing the fresh roots from five sample plants 20 days after sowing.

6. Seedling shoot fresh weight (g plant ${ }^{-1}$ ): this was gathered by weighing the fresh shoots from five sample plants 20 days after sowing.

7. Root to shoot ratio: this was gathered by computing and recording the ratio of fresh roots and shoots from five sample plants 20 days after sowing. This was done using the formula:

Root $/$ Shoot Ratio $=\frac{\text { Fresh wt. of plant shoots }}{\text { Fresh wt. of plant roots }}$

8. Nodules (plant ${ }^{-1}$ ) were gathered by counting the number of nodules produced from the five sample peanut plants 30 days after sowing.

\section{Data Analysis}

All data gathered were analyzed using the statistical tool for agricultural research to analyze variance. The comparison of treatment means was done using the honestly significant difference test.

\section{Results and Discussion}

The germination performance of peanuts as influenced by hydro-priming and seed size is presented in Table 1. The process of germination is defined as a sequence of stages beginning with the uptake of water (imbibition) and leading to the rapture of the seed coat by the radicle (embryonic roots) or the plumule (embryonic shoot). Cell division and enlargements in the embryo and the overall increase in metabolic activity accompany these steps. Although actual germination begins long before the seed coat's rupture, the germination is usually determined visibly by observing the protrusion of the radicle on the shoot.

\section{Under Laboratory Condition}

\section{Effects of seed size on germination}

The result of the study revealed that most of the germination parameters, except the mean germination speed (seeds day ${ }^{-1}$ ), and mean germination time were significantly affected by the seed size (Table 1).

Bigger size contributed to the ability of the large seeds to emerge faster than the smaller ones. Likewise, final germination was enhanced in the bigger seeds, resulting in an increase in the germination index (seeds day ${ }^{-1}$ ) and the SVI. These results can be attributed to the ability of the whole and bigger seeds that were characterized by the complete seed part/active enzyme when triggered by the absorbed water it imbibed and initiated the protrusion of the young shoot ready to come out for germination (Matthews \& Hosseini, 2007).

Results of this study conform to the findings of Papong and Cagasan (2020) that light seeds had a significantly lower percentage of germination, vigor, and other agronomic parameters evaluated compared to heavier seeds. The results showed the advantages of the heavier or bigger seeds, which are characterized by full enzymatic elements inside the seeds such as the endosperm, cotyledon, and seed coat which gave the seeds a full nutrition during germination and early development. Thus, 
Table 1.

Germination Performance of Peanut Seeds as Influenced by Priming and Seed Size under Laboratory Conditions

\begin{tabular}{|c|c|c|c|c|c|c|}
\hline Treatments & $\begin{array}{c}\text { Final } \\
\text { Germination (\%) }\end{array}$ & $\begin{array}{l}\text { Timson's Germination } \\
\text { Index (Seeds Day }{ }^{-1} \text { ) }\end{array}$ & $\begin{array}{l}\text { Germination Speed } \\
(\text { Seeds Day-1) }\end{array}$ & $\begin{array}{c}\text { Germination } \\
\text { Time (Day) }\end{array}$ & $\begin{array}{l}\text { Mean Daily } \\
\text { Germination }\end{array}$ & $\begin{array}{l}\text { Seed Vigor } \\
\text { Index }\end{array}$ \\
\hline \multicolumn{7}{|l|}{ Seeds size } \\
\hline Large & $91.67^{\mathrm{a}}$ & $17.78^{a}$ & 0.76 & 7.56 & 12.12 & $21.14^{a}$ \\
\hline Small & $87.00^{b}$ & $14.58^{b}$ & 0.77 & 7.67 & 11.34 & $17.12^{\mathrm{b}}$ \\
\hline Ftest & $*$ & $*$ & ns & ns & ns & $*$ \\
\hline$\% \mathrm{CV}$ & 8.32 & 3.87 & 5.07 & 3.68 & & 5.98 \\
\hline \multicolumn{7}{|l|}{ Priming } \\
\hline $\mathrm{T}_{1}-{ }_{0}$ hour priming & $80^{b}$ & $14.96^{b}$ & $0.67^{b}$ & $9.67^{\mathrm{b}}$ & $8.27^{\mathrm{b}}$ & $16.45^{b}$ \\
\hline $\mathrm{T}_{2}-{ }_{5}$ hours priming & $94^{a}$ & $19.50^{\mathrm{a}}$ & $0.80^{a}$ & $7.00^{\mathrm{a}}$ & $13.42^{\mathrm{a}}$ & $19.55^{a}$ \\
\hline $\mathrm{T}_{3}-{ }_{10}$ hours priming & $95^{\mathrm{a}}$ & $15.58^{b}$ & $0.82^{a}$ & $7.17^{\mathrm{a}}$ & $13.24^{\mathrm{a}}$ & $20.53^{a}$ \\
\hline Ftest & $*$ & $*$ & $*$ & $*$ & $*$ & * \\
\hline $\begin{array}{l}\text { Seed size } \times \\
\text { priming interaction }\end{array}$ & ns & ns & ns & ns & ns & ns \\
\hline$\% \mathrm{CV}$ & 4.76 & 10.43 & 6.09 & 4.89 & 7.23 & 5.73 \\
\hline
\end{tabular}

these seeds were able to exhibit good performance in most of the parameters evaluated.

\section{Effects of hydro-priming on germination}

Table 1 presents the effects of hydro-priming on peanut seeds under drought condition. All of the parameters were significantly affected by the hydro-priming treatments. Large seeds soaked at 5-10 hours emerged earlier than the unsoaked seeds (not subjected to hydro-priming). These results can be attributed to the amount of moisture absorbed by the seeds, which is a significant factor in seed germination. Similarly, presoaking of seeds before planting initiated the germination process. It should be noted, though, that during planting at the field, growth may be arrested under dry field conditions with a potential loss of seed viability. Under drought conditions, there is a shallow moisture content of the soil in the field, and priming of seeds for 5-10 hours can help increase or facilitate the seeds' germination. Little irrigation may favor the emergence of small seeds. Moisture levels should be enough to allow seeds to imbibe water, germinate, and emerge above the soil surface. Under insufficient moisture, small seeds may imbibe water, germinate, but die later.

\section{Under Nursery Condition}

\section{Effects of hydro-priming and seed size on root and shoot length and weight}

Table 2 presents the root and shoot length and weight of peanut 20 days after sowing as influenced by priming and seed size. Results revealed that only shoot length $(\mathrm{cm})$ and root weight (g) were significantly affected by the seed size and seed priming treatments. Large seeds had a shorter length of shoots but heavier root weight. This result can be attributed to the bigger seed size that produced shorter but broader shoots and heavier root weight. This result conforms to the findings of Khan et al. (2009) that seedling vigor and broader with shorter shoots but heavier shoot weight was significantly noted when using bigger seeds as planting materials. Seeds soaked in water at 5 and 10 hours significantly increased the shoot length and eventually obtained the heavier root weight as compared to the unprimed seeds. These results can be attributed to the effects of water that help facilitate the activation of the seed enzymes that also facilitated rapid germination (Taiz \& Zeiger, 2002) and resulted in the early development of shoots and roots even under drought conditions. Moreover, Rafiq et al. (2006) reported the advantage of seed priming under problem soils. According to them, priming reduces the effect of salinity on the morphological parameter of the plants. A low-cost approach, designated as on-farm seed priming, was proposed by Harris (2019) and involved soaking of seed in water before sowing in the dry soil. This pre-sowing seed treatment, known as hydro-priming, allow the seeds to imbibe water and go through the first phase of germination in which pregermination metabolic activities are started while the latter two phases of germination are inhibited (Pill \& Necker, 2011). Moreover, Roy and Srivastava (2019) reported that soaking wheat kernels in water improved their germination rate even under dry conditions.

The interaction effect was noted on the fresh shoot weight (FSW) of peanut plants as affected by seed size and hyro-priming (Table 3). Results revealed a significantly higher FSW of peanut plants when exposed to priming regardless of seed size. This can be attributed to the differences in the seed size that absorbed more moisture for the development of the seeds like the germination and shoot development. This conformed to the report of Ashraf and Foolad (2005) that pre-sowing seed treatment a shotgun approach to improve germination, plant growth, and crop yield under saline and non-saline conditions.

\section{Effects of hydro-priming and seed size on seed emergence, flowering, plant height, and number of nodules}

Table 4 presents the seed emergence, flowering, plant height (cm), and number of nodules per plant 20 days after sowing as influenced by hydro-priming and seed size. Results revealed that all parameters were significantly affected by the seed size. Seedlings from the small seeds grow longer than those coming from the bigger seeds. This result can be attributed to the characteristics of the smaller seeds to grow thinner and longer stems to capture solar radiation for its photosynthetic activity (Papong \& Cagasan, 2020). Meanwhile, bigger seeds produced broader 
Table 2.

Root and Shoot Performance of Peanut 20 days after Sowing as Influenced by Hydro-priming and Seed Size (Figure 2a-d)

\begin{tabular}{|c|c|c|c|c|c|}
\hline Size of Seeds & Root Length (cm) & Shoot Length $(\mathrm{cm})$ & Fresh Root Weight (g) & Fresh Shoot Weight (g) & Fresh Root to Shoot Ratio \\
\hline Large & 9.78 & $9.39^{b}$ & $0.19^{a}$ & 1.30 & 0.15 \\
\hline Small & 9.57 & $10.19^{a}$ & $0.16^{b}$ & 1.16 & 0.15 \\
\hline Ftest & ns & * & $*$ & ns & ns \\
\hline$\% \mathrm{CV}$ & 10.65 & 2.43 & 10.23 & 8.56 & 3.23 \\
\hline \multicolumn{6}{|l|}{ Priming } \\
\hline $\mathrm{T}_{1}-{ }_{0}$ hour priming & 9.83 & $8.55^{\mathrm{b}}$ & $0.17^{\mathrm{b}}$ & 1.10 & 0.17 \\
\hline $\mathrm{T}_{2}-{ }_{5}$ hours priming & 9.30 & $10.16^{\mathrm{a}}$ & $0.18^{\mathrm{a}}$ & 1.41 & 0.13 \\
\hline $\mathrm{T}_{3}-{ }_{10}$ hours priming & 9.88 & $10.67^{a}$ & $0.18^{a}$ & 1.19 & 0.14 \\
\hline Ftest & ns & $*$ & $*$ & ns & ns \\
\hline $\begin{array}{l}\text { Seed size } \times \\
\text { priming interaction }\end{array}$ & ns & ns & $*$ & ns & ns \\
\hline$\% \mathrm{CV}$ & 11.34 & 5.90 & 12.32 & 10.56 & 7.54 \\
\hline
\end{tabular}

Table 3.

Interaction Effect on the Fresh Root Weight (g) of Peanuts Affected by Seed Size and Hydro-priming

\begin{tabular}{|l|c|c|}
\hline \multirow{2}{*}{ Priming } & \multicolumn{2}{|c|}{ Seed Size } \\
\cline { 2 - 3 } & Smaller & Larger \\
\hline$T_{1-0}$ hour priming & $18.12^{\mathrm{b}}$ & $19.09^{\mathrm{b}}$ \\
\hline$T_{2-5}$ hours priming & $19.65^{\mathrm{a}}$ & $20.98^{\mathrm{a}}$ \\
\hline$T_{3-10}$ hours priming & $19.09^{\mathrm{a}}$ & $21.54^{\mathrm{a}}$ \\
\hline
\end{tabular}

Columns having the same letter(s) are not significantly different from each other at $5 \%$ level of significance, HSD test.

stems which grew sideward, thus obtaining shorter plant height. According to Sarcol and Cagasan (2016), seed size in general can influence seedling development. Smaller seeds produced longer plant shoots and plant height (Table 4) but with lesser number of leaves. On the other hand, bigger seeds produced more number of nodules than smaller ones. This result can be attributed to the advantage of bigger seeds that can develop early, and after 20 days it can produce more nodules. Likewise, 50\% emergence and number of nodules plant ${ }^{-1}$ were significantly affected by hydro-priming. Seeds soaked in water at 5 and 10 hours emerged significantly earlier than the unprimed seeds. This result can be attributed to the absorbed moisture during priming. Primed seeds have the advantage over unprimed ones because of the limited moisture present in the dry soil conditions. Thus, unprimed seeds were not able to absorb moisture needed by the seeds for germination. Seeds primed for 5 and 10 hours produced significantly more nodules per plant than plants from unprimed seeds. The result showed that 5 hours priming provide enough time for the seeds to absorb enough moisture ready for imbibition resulting in rapid germination (Abandani \& Ramezani, 2012).

\section{Conclusion and Recommendation}

Based on the results of this study, it can be concluded that presowing seed treatment at 5 and 10 hours showed a favorable germination rate at $94 \%$ and $96 \%$, respectively. Hydro-priming activity allowed the seeds to imbibe water and go through the first phase of germination in which pre-germination metabolic activities started. Rapidly germinating seedlings could emerge and

Table 4.

Emergence, Flowering, Plant Height (cm), and Number of Nodules Plant ${ }^{-1}$ of Peanut 30 Days After Sowing (Figure 2a-d)

\begin{tabular}{|c|c|c|c|c|}
\hline Size of Seeds & Days to $50 \%$ Emergence & Days to $50 \%$ Flowering & Plant Height (cm) & Number of Nodules Plant ${ }^{-1}$ \\
\hline Large & $9^{a}$ & 29 & $27.98^{b}$ & $20^{a}$ \\
\hline Small & $7^{\mathrm{b}}$ & 30 & $32.87^{a}$ & $15^{\mathrm{b}}$ \\
\hline$\% \mathrm{CV}$ & 13.32 & 11.90 & 12.43 & 3.23 \\
\hline \multicolumn{5}{|l|}{ Priming } \\
\hline $\mathrm{T}_{3}-10$ hours priming & $7^{\mathrm{a}}$ & $27^{\mathrm{a}}$ & 27.45 & $19^{\mathrm{a}}$ \\
\hline Ftest & * & * & $\mathrm{ns}$ & * \\
\hline Seed size $\times$ priming interaction & ns & ns & ns & ns \\
\hline$\% \mathrm{CV}$ & 12.76 & 13.25 & 8.94 & 12.32 \\
\hline
\end{tabular}



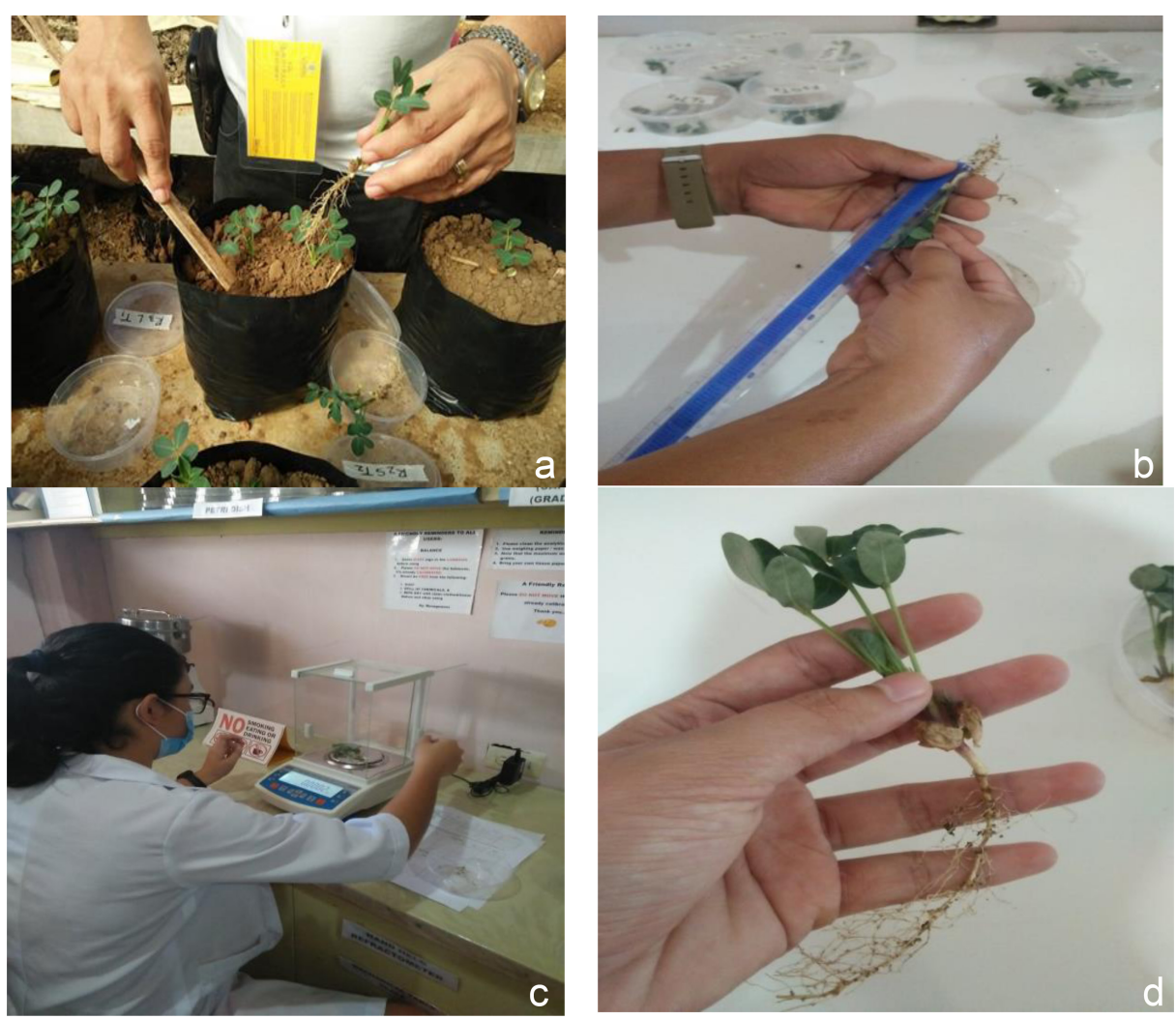

Figure 2. a-d.

Activities in the Nursery (Pot Experiment) and in the Laboratory Measuring and Weighing the Sample Plants. Data Gathered in These Activities are Presented in Tables 2-4. (a) Gathering Samples for Shoot and Root Length and Weight Measurements, (b) Measuring Root and Shoot Length, (c) Measuring Shoot and Root Weight, (d) Sample Plant for Data Collection

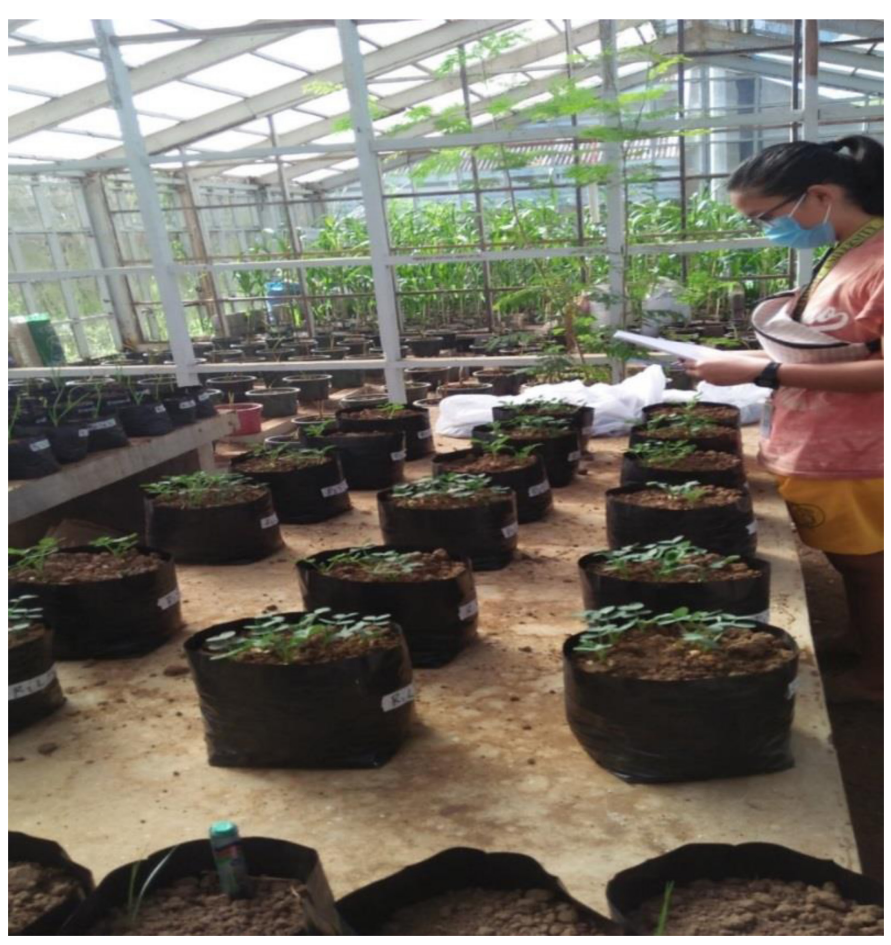

Figure 3.

Peanut Seedlings in the Nursery at 12 Days after Sowing. produce deep roots before the upper layers of the soil are dried out and become crusted, which may result in good crop establishment and obtain higher crop yield. Likewise, under drought conditions where soil moisture is insufficient, small seeds may imbibe and germinate, but some will die. However, in large seeds, imbibed water may be insufficient to trigger germination, and such seeds may emerge later when conditions improve. Moreover, interaction effect was noted on the FSW of peanut plants as affected by seed size and hyro-priming. Results revealed a significantly higher FSW of peanut plants when exposed to priming regardless of seed size.

It is recommended that bigger seeds can be a good source of planting materials when planted in drought conditions and primed at 5-10 hours. However, unprimed smaller seeds can be used in moist conditions. Likewise, it is further recommended to continue the study up to harvesting maturity to assess the effects of seed size and seed priming duration on the yield and yield component parameters of the peanut crop.

\section{Ethics Committee Approval: N/A.}

Peer-review: Externally peer reviewed.

Author Contributions: Concept - V.M.E.C., U.C.; Design - V.M.E.C., U.C.; Supervision - U.C.; Resources - V.M.E.C.; Materials - V.M.E.C.; Data Collection and/ or Processing - V.M.E.C.; Analysis and/ or Interpretation V.M.E.C.; Literature Search - V.M.E.C.; Writing Manuscript - V.M.E.C., U.C.; Critical Review -U.C. 
Conflict of Interest: The authors declared that no conflict of interest on this article submission.

Financial Disclosure: The authors declared that this study has received no financial support.

Etik Komite Onayı: N/A.

Hakem Değerlendirmesi: Dış Bağımsız.

Yazar Katkıları: Fikir - V.M.E.C., U.C.; Tasarım - V.M.E.C., U.C.; Denetleme U.C.; Kaynaklar - V.M.E.C.; Malzemeler - V.M.E.C.; Veri Toplanması ve/veya Işlemesi - V.M.E.C.; Analiz ve/veya Yorum - V.M.E.C.; Literatür Taraması V.M.E.C.; Yazıyı Yazan - V.M.E.C., U.C.; Eleştirel İnceleme - U.C.

Çıkar Çatışması: Yazarlar çıkar çatışması bildirmemişlerdir.

Finansal Destek: Yazarlar bu çalışma icin finansal destek almadıklarını beyan etmişlerdir.

\section{References}

Abandani, R. R., \& Ramezani, M. (2012). The physiological effects on some traits of osmopriming germination of maize (Zea mays L.), rice (Oryza sativa L.) and cucumber (Cucumis sativus L.). International Journal of Agronomy, 4(2), 4132-4148.

Adinya, I. B., Enun, E. E., \& Ijoma, J. U. (2016). Exploring profitability potentials in groundnut production through agroforestry practices: A case study in Nigeria. Journal of Animal and Plant Sciences, 20(2), 123-131.

Al-Soqueer, A. A. (2004). The potential of seed soaking in sorghum (Sorghum bicolor (L.) Moench) production [PhD thesis]. UK: University of Nottingham.

Ashraf, M., \& Foolad, M. R. (2005). Pre-sowing seed treatment a shotgun approach to improve germination, plant growth, and crop yield under saline and non-saline conditions. Advances in Agronomy, 88, 223-271. [CrossRef]

Ashraf, M., \& Iram, A. (2012). Optimization and influence of seed priming with salts of potassium or calcium in two spring wheat cultivars differing in salt tolerance at the initial growth stages. Agro Chimica, 46, 47-55.

Ashraf, M., \& Rauf, H. (2001). Inducing salt tolerance in maize (Zea mays L.) through seed priming with chloride salts: Growth and ion transport at early growth stages. Acta Physiologiae Plantarum, 23(4), 407-414. [CrossRef]

Black, J. N. (1957). The early vegetative growth of three strains of subterranean clover (Trifolium subterraneum L.) in relation to size of seed. Australian Journal of Agricultural Research, 8(1), 1-14. [CrossRef]

Chivassa, W., Harris, D., Chiduza, C., \& Nayamudiza, P. (2000). Determination of optimum on-farm seed priming time for maize (Zea mays L.) and Sorghum (Sorghum bicolor L.) to improve stand establishment in semi-arid agriculture. Tanzanian Journal of Agricultural Science, 2, 103-112.

Ekpo, J. (2004). Does seed size affect the rate of germination and early seedling growth in Hairy Vetch? (McCabe Thesis Collection, Paper, 19).

Harris, D., Pathan, A. K., Gothkar, P., Joshi, A., Chivasa, W., \& Nyamudeza, P. (2001). On-farm seed priming: Using participatory methods to revive and refine a key technology. Agricultural Systems, 69(1-2), 151-164. [CrossRef]

Khan, H. A., Ayub, C. M., Pervez, M. A., Balal, R. M., Shahid, M. A., \& Ziaf, K. (2009). Effect of seed priming with $\mathrm{NaCl}$ on salinity tolerance of hot pepper (Capsicum annuum L.) at seedling stage. Soil and Environment, 28, 81-87.

Longer, D. E., Lorenz, E. J., \& Cothren, J. T. (2006). The Influence of seed size in Soybean emergence under simulated soil crust conditions. Field Crops Research, 14(4), 371-375.

Matthews, S., \& Khajeh-Hosseini, M. K. (2007). Length of the lag period of germination and metabolic repair explain vigor differences in seed lots of maize (Zea mays L). Seed Science and Technology, 35(1), 200-212. [CrossRef]

Papong, J. R., \& Cagasan, U. A. (2020). Growth and yield performance of upland rice (Oryza sativa L. var. zambales) intercropped with Mungbean (Vigna radiata L.) and peanut (Arachis hypogaea L.). International Journal of Agriculture Forestry and Life Sciences, 3(1), 264-269.

Pepper, G. E. (2002). Will it make a difference? University of Illinois. Retrieved from http://www.ag.uiuc.edu/ stratsoy/expert/soysize. html.

Pill, W. G., \& Necker, A. D. (2001). The effects of seed treatments on germination and establishment of Kentucky bluegrass (Poa pratense L.). Seed Science and Technology, 29, 65-72.

Rafiq, S., Iqbal, T., Hameed, A., Rafiqi, N., \& Rafiq, Z. A. (2006). Morphochemical analysis of salinity stress response of wheat. Pakistan Journal of Botany, 38, 1759-1767.

Sanderson, M. A., Skinner, R. H., \& Elwinger, G. F. (2002). Seedling development and field performance of prairiegrass, grazing bromegrass, and orchardgrass. Crop Science, 42(1), 224-230. [CrossRef]

Sarcol, B. P., \& Cagasan, U. A. (2016). Performance of peanut (Arachis hypogaea) as influenced by time of planting sweetpotato (Ipomea batatas L.) as intercrop. Annals of Tropical Research, 38, 122-133.

Singn, S. P., \& Rai, P. N. (1988). Effect of seed size upon germination and early stages of plant growth of cowpea (Vigna unguiculata L.). Acta Horticulturae, 12(218), 71-76. [CrossRef]

Taiz, L., \& Zeiger, E. (2002). Plant physiology (3rd ed). Sunderland, MA: Sinauer Associates, Inc. Publishers.

Taru, V. B., Khagya, I. Z., Mshelia, S. I., \& Adebayo, E. F. (2018). Economic efficiency of resource use in groundnut production in Adamawa State of Nigeria. World Journal of Agricultural Science, 56, 4896-4900. 